\title{
Conversação eleitoral em democracias monitoradas: uma tipologia para análise de comentários em redes sociais on-line
}

\author{
Emerson Urizzi Cervi (UFPR)' \\ Fernanda Cavassana de Carvalho (UEPG/UFPR) ${ }^{2}$
}

\section{Resumo}

O artigo discorre sobre como a abundância comunicativa potencializada pelos espaços on-line afeta a organização das conversações democráticas contemporâneas. Discute-se como os monitores sociais geram fluxos de comunicação próprios, especialmente nas redes sociais on-line, direcionados a instituições e atores políticos. Analisa-se o comportamento do debate on-line sobre as eleições de 2014 no Brasil a partir de 610 mil comentários feitos às fanpages no Facebook da Folha de S. Paulo, do Estadão e de O Globo. A pergunta de pesquisa respondida é: os comentadores dos três jornais apresentam comportamentos similares ou distintos? Além disso, propõe-se

I Professor associado do Departamento de Ciência Política; professor permanente do programa de pós-graduação em Ciência Política e do programa de pós-graduação em Comunicação da Universidade Federal do Paraná (UFPR). Possui doutorado em Ciência Política pelo Instituto Universitário de Pesquisas do Rio de Janeiro (luperj) e estágio pós-doutoral em partidos e eleições na Faculdade Latino-americana de Ciências Sociais - Espanha (Flacso-es)/Universidad Salamanca. Coordena o grupo de pesquisa em Comunicação Política e Opinião Pública (CPOP), com pesquisas e publicações nas áreas de debate e opinião pública, eleições, partidos, comunicação eleitoral, financiamento de campanhas e metodologia de pesquisa. Endereço: Universidade Federal do Paraná, Departamento de Ciência Política. Rua General Carneiro, 460, Ed. Dom Pedro I, $9^{\circ}$ andar, sala 908. Centro. CEP: 80060-150, Curitiba,PR - Brasil.E-mail: ecervi7@gmail.com

2 Professora colaboradora do Departamento de Jornalismo da Universidade Estadual de Ponta Grossa (UEPG). Doutoranda em Ciência Política e mestra em Comunicação pela Universidade Federal do Paraná (UFPR), onde é membro do grupo de pesquisa em Comunicação Política e Opinião Pública (CPOP). Atua em pesquisas sobre internet e política; conversações digitais; redes sociais on-line; jornalismo político; mídia e eleições. Endereço: Departamento de Jornalismo - Universidade Estadual de Ponta Grossa. Campus Central. Praça Santos Andrade, n. 0 I - Centro. CEP84010-790. Ponta Grossa-PR. E-mail: cavasanaf@gmail.com Commons. Com essa licença você pode compartilhar, adaptar, para qualquer fim, desde que atribua a autoria da obra, forneça um link para a licença, e indicar se foram feitas alterações. 
uma tipologia para classificar os comentários. Entre os resultados obtidos, tem-se que o volume de ruído no debate eleitoral digital é superior aos comentários temáticos.

Palavras-chave: Democracia monitorada. Conversação digital. Eleições 2014. Ruído. Monitores.

\section{Introdução}

Este artigo ${ }^{3}$ discute como a abundância comunicativa potencializada pelos espaços on-line afeta a organização do debate público contemporâneo, especialmente pela atuação de monitores sociais independentes ${ }^{4}$. Tendo como principal aporte o conceito de democracia monitorada ${ }^{5}$ de John Keane (2010), apresentamos uma discussão teórica que abrange questôes acerca do debate público, os seus principais agentes e os fluxos de comunicação entre eles. Empiricamente, são descritos comportamentos das conversaçôes on-line, sobre as eleiçóes de 2014 no $\mathrm{Brasil}^{6}$, que indicam o tipo de participação que monitores acabam apresentando, atualmente, nos ambientes digitais. Essa participação, em excesso, também gera ruídos no debate construído nesses ambientes.

Consideramos que as novas tecnologias não só permitiram o maior acesso a informaçóes e a discussóes sobre temas públicos mas também fizeram da internet uma ampliaçáo enviesada da esfera pública moderna enquanto espaço de ressonância da demanda social aos seus representantes (SCHÄFER, 2015). As redes digitais se apresentam como ferramentas propícias às novas formas de representação, assinaladas como mais próximas e interativas, diretas e permanentes (COLEMAN, 2005). Contudo, as novas características da comunicação política no ciberespaço podem levar a resultados inesperados. Primeiramente, porque os atuais fluxos de comunicação e expressão de opinião on-line não necessariamente conduzem o debate público a um consenso (GROSSI, 2011), o que se espera normativamente.

\footnotetext{
3 Uma versão preliminar foi apresentada no 41 Encontro Anual da Anpocs, em 2017.

4 Como definido adiante, são considerados monitores sociais aqueles atores que pertencem à sociedade e se manifestam de maneira isolada, sem vínculos com organizações tradicionais de representação ou com os meios de comunicação. A participação deles tem o objetivo principal de fiscalizar o conteúdo ou a qualidade de alguma instituição ou tema que integra o debate público.

5 Optamos por uma tradução livre de "monitory democracy".

6 Com dados da pesquisa "Opinião Pública e debate político na web", desenvolvida no âmbito do grupo CPOP (www.cpop.ufpr.br).
} 
Em segundo lugar, a intensidade e o volume de informação política em rede podem contribuir para o desgaste das relaçóes representativas.

Essa era de excessos comunicativos evidencia despontamentos, contradiçôes e instabilidade política refletidos no debate público (KEANE, 2010). Os excessos não são apenas em termos quantitativos, mas também no tipo de participação, quando não relacionada diretamente aos assunto que pautam as conversaçóes. Ademais, isso potencializa uma crise de representatividade evidenciada nas sociedades desenvolvidas e compreendida como um potencial perigo às democracias (HELD, 1996) - que não se restringe às instituiçôes e aos atores políticos. Instituiçôes sociais relevantes ao fortalecimento de democracias representativas, como a mídia (SCHUDSON, 2008), também passam a ser questionadas pela própria sociedade.

Essa discussão considera que a participação dos monitores sociais tem potencial para dificultar o andamento das conversaçôes, seja pela independência na forma e conteúdo da participação, seja no volume extra de inputs para o debate público. Assim, a presença de monitores sociais no debate público cria uma tensão no modelo tradicional e inclui um volume de conteúdos que são chamados de "ruídos", pois não se aplicam à discussão institucional, mas às críticas diretas às organizaçôes sociais, mídia ou instituiçóes estatais. Este "ruído" é o que pretendemos definir empiricamente e analisar aqui. Toda atividade monitoral é um ruído para o tema em debate, pois não aborda o assunto propriamente dito, dirige-se à instituição que intermedeia as discussões. No entanto, nem todo ruído é do tipo monitor, pois ele pode ser totalmente desprovido de conteúdo em relação ao tema e em relação às instituiçôes. No caso em discussão aqui, os monitores geram ruído ao debate eleitoral quando integram as conversaçôes em Facebook para monitorar a postura dos jornais. Além disso, há uma profusão de comentários que são considerados apenas ruído por não tratarem do tema e não monitorarem o comportamento dos jornais analisados aqui.

Nosso objetivo geral neste artigo é caracterizar o comportamento dos monitores independentes via comentários em páginas que alimentaram o debate eleitoral por meio das RSO nas últimas eleiçóes presidenciais. Especificamente, propomos: i) apresentar uma tipologia que classifique os comentários a partir do comportamento do público na conversação 
digital; ii) comparar os tipos de comentários por jornal e por menção aos candidatos; iii) averiguar quais as implicaçôes da variável tempo no comportamento dos três tipos considerados. Com isso, pretendemos responder a: como se comportaram os comentadores de cada portal no período eleitoral de 2014 no Facebook?

$\mathrm{O}$ artigo segue dividido em três principais partes. $\mathrm{O}$ tópico a seguir discorre sobre o conceito de democracia monitorada (KEANE, 2010) e sobre como os próprios indivíduos comportam-se como monitores individuais e independentes (SCHUDSON, 1998). A seção teórica também disserta sobre a definição de ruído adotada aqui, como uma das consequências negativas do excesso de participação do tipo monitor no debate digital. O segundo tópico teórico passa a considerar as características do debate pertinentes ao nosso objeto empírico, uma vez que o tipo de conversação analisado se dá via comentários a publicaçóes jornalísticas sobre eleiçóes no Facebook.

O terceiro tópico descreve os procedimentos metodológicos e desenvolve a análise exploratória dos dados, em três etapas. Na primeira, apresentamos uma tipologia para classificar os comentários e testamos a consistência interna dos tipos: monitor, temático ou ruído. Na segunda, exploramos a relação entre a tipologia dos comentários por fanpage e presença ou não dos dois candidatos que foram ao segundo turno (Dilma Rousseff - PT e Aécio Neves - PSDB) nos comentários. A terceira trata da exploração dos dados utilizando técnicas específicas de séries temporais. Ao final, apresentamos nossas conclusóes a partir dos resultados obtidos.

\section{Abundância comunicativa e redes sociais on-line: monitoramento e ruídos nas conversações digitais}

Considera-se que a opinião pública é um processo social complexo, composto, principalmente, por duas dimensóes: a participação no debate público e o acesso a informaçóes públicas (GROSSI, 2007). Não é nosso objetivo aprofundar a discussão do conceito ou aplicá-lo em geral ao caso do debate público brasileiro. Nossa intenção é considerar essa delimitação teórica como ponto de partida e usá-la como norte para nosso objeto empírico. Para isso, consideramos o debate público intrínseco à sociedade e 
ao processo de formação da sua opinião coletiva e que ele, hoje, engloba uma diversidade de atores, temas e arenas, inclusive aquelas digitais como as redes sociais, em que se dão conversaçóes como a analisada aqui.

Em democracias representativas consolidadas, o debate público comporta três principais agentes - o Estado; a mídia ${ }^{7}$ e a sociedade civil - e tem local delimitado entre as fronteiras do Estado e da Sociedade. Nesse contexto de debate, o fluxo de comunicação é verticalizado e com direçôes predefinidas (KEANE, 2010). Tradicionalmente, sociedade e Estado apresentam seus conteúdos institucionalmente, via organizaçóes sociais de um lado e instituiçôes estatais de outro. Além dessa relação direta, há um conjunto de instituiçôes sociais especializadas em organizar, produzir e difundir conteúdos para o debate entre Estado e sociedade, a mídia (CERVI, 2010). Assim, os meios de comunicação intermedeiam o debate, inclusive dando visibilidade a determinados temas e enquadramentos (FUKS, 2000), constituindo-se como espaço hegemônico de publicização das demandas sociais e das açóes políticas (RUBIM, 2001). Dentro da temática eleitoral, por exemplo, tradicionalmente, a cobertura jornalística é fundamental para apresentar os candidatos e suas propostas e manter os eleitores informados sobre a disputa ao longo da campanha.

Ao expor o desgaste da representatividade tradicional no debate público, Keane (2010) propóe o conceito de democracia monitorada, um novo tipo de democracia que passa a ser caracterizada por ampla discussão política náo institucionalizada, diluída e horizontal. Nessa nova conjuntura, expandem-se as formas e os espaços de controle e cobranças sobre a prática política, desorganizando a estrutura de Estado que se encontrava fortalecida nas democracias representativas, e, por isso, transcendendo os limites do próprio Estado. Segundo Keane (2010), a novidade é o surgimento dos monitores sociais, que pertencem à sociedade, mas náo estáo integrados às organizaçóes tradicionais, nem à mídia. Monitorar é compreendido como o processo de fiscalizar sistematicamente o conteúdo ou a qualidade de algo. A lista do autor engloba diversos tipos de monitores, incluindo júris de conselhos consultivos, assembleias regionais, orçamento participativo,

Aqui compreendida como o conjunto de veículos de comunicação de massa de uma sociedade, o que inclui Jornalismo e entretenimento, de diferentes formatos. 
grupos focais e, inclusive, cidadãos individuais, que agem de maneira particularizada. O quadro a seguir apresenta uma adaptação das categorias apresentadas por Keane (2010) para o debate público no novo desenho das fronteiras das democracias monitoradas.

Quadro I - Fluxos comunicativos do debate em democracias monitoradas

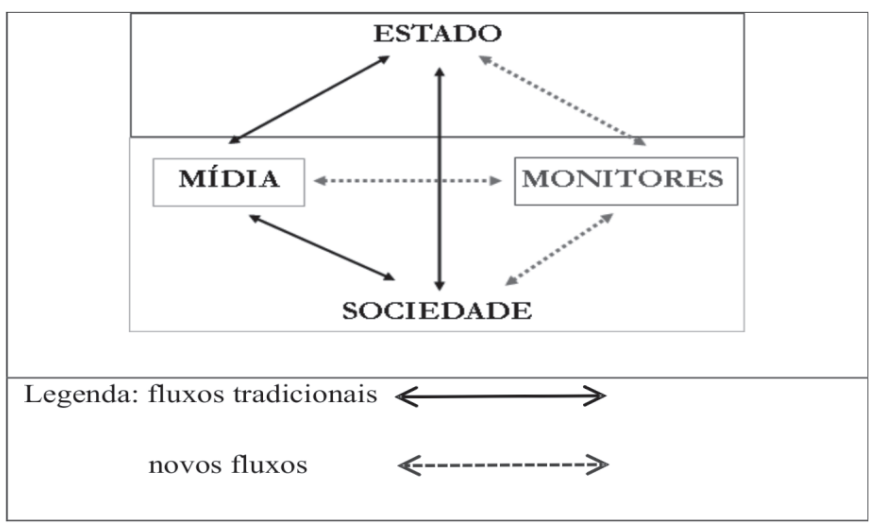

Fonte: Elaboração dos autores, a partir de Keane (2010).

Como Keane (2010) trata das mudanças na democracia por uma perspectiva histórica, a compreensão desse novo tipo de democracia está estritamente ligada ao crescimento de sociedades saturadas por múltiplos meios de informação (FEENSTRA, 2012). É o que Keane (2010) define como "abundância comunicativa". Para ele, foi a configuração de uma nova galáxia midiática, especialmente potencializada pela internet, que deu suporte para a atuação do controle da política por parte desses monitores (KEANE, 2010), uma vez que se expandem as formas de publicação, acesso e consumo de informaçóes, principalmente, políticas. Segundo Keane (2010), a combinação da democracia monitorada com a abundância comunicativa produz um fluxo permanente e inquietante, marcado por combinaçóes completas entre atores e instituiçóes, que passam a interagir muitas vezes em oposição uns aos outros.

Acreditamos que Keane (2010) não esteja errado ao descrever as mudanças nessas relaçôes, assim como não negamos que exista um perigo em 
potencial destas para a própria democracia representativa quando há excesso de desconfiança nas suas instituições. Contudo, defendemos que não é necessariamente o monitoramento que conduz as democracias a crises de representatividade. Partindo do excesso de informação nessa conjuntura, podemos considerar dois pontos distintos da abundância comunicativa para a democracia a partir de Keane (2010). De um lado, a nova galáxia midiática chama atenção e amplia o horizonte das pessoas para os assuntos políticos. Por outro, a sociedade saturada de mensagens estimulam as pessoas a desconfiarem dos representantes. Portanto, o comportamento monitor é muito mais consequência da perda de confiança do que causa disso.

Para Moisés e Meneguello (2013), a confiança diz respeito à segurança e à expectativa das pessoas na democracia e nas suas instituiçóes e depende de uma série de fatores que, se levados ao fracasso, geram, nas pessoas, a desconfiança política e no sistema democrático. Para os autores, os conteúdos institucionais normativos são o objeto central da confiança. "Essa desconfiança resultaria, assim, tanto da avaliação racional das pessoas em relação aos resultados práticos do desempenho das instituiçóes, como da percepção de que seus fundamentos normativos não estão se realizando" (MOISÉS; MENEGUELLO, 2013, p. 17). É por isso que ao longo do último século foram desenvolvidas várias outras formas e organizaçóes, fora dos limites do Estado, para fiscalizar e acompanhar o desempenho e funcionamento do sistema democrático e de suas instituiçóes, como os observatórios municipais de gestão pública, por exemplo. Neste artigo, tratamos de um tipo de monitor, individual e não institucionalizado, que pode desgastar o debate público, portanto, essencialmente ligado à abundância comunicativa, não institucionalizada nem mediada: o comentador on-line.

Ao menos no que se restringe ao debate público, ampliado de forma enviesada na esfera digital, especialmente nas redes sociais on-line, acreditamos que o principal efeito da abundância comunicativa e do monitoramento é a ampliação do ruído no processo comunicativo. O que é potencializado pelos novos fluxos de comunicação. Assim, não é necessariamente o monitoramento das instituiçóes sociais e democráticas que desgastam a relação de representatividade e podem gerar, qualitativamente, efeitos nocivos às democracias contemporâneas. Mas, alguns tipos específicos de manifestaçóes - como as evidenciadas em RSO via comentários - desses 
monitores, que levam a um estresse do debate público, tradicionalmente não preparado para suportar o excesso de participação refletido na quantidade de novos fluxos e atores que surgem no ambiente digital. Compreendemos que é esse comportamento que sobrecarrega, com ruídos, as conversaçóes que integram o debate contemporâneo.

Compreende-se como ruído ${ }^{8}$ qualquer interferência no processo de transmissão da informação que pode prejudicar a comunicaçáo. Aqui, contudo, o ruído não é determinado pelo aparato tecnológico, como uma falha técnica do canal ou ambiente onde se dá a comunicação. É justamente o comportamento do indivíduo que integra esse processo comunicativo que gera ruído nesses espaços, uma vez que, ao aumentar o fluxo de informações em direção aos demais atores do processo, impede que haja uma comunicação eficaz. Assim, em um processo mais amplo, como as conversações digitais, o ruído é aquela manifestação que prejudica a comunicação entre os atores envolvidos.

Quando não se torna ruído, o monitoramento das instituiçôes pode gerar resultados positivos à democracia, uma vez que a fiscalização e a cobrança podem ser compreendidas também como um retorno do interesse do cidadão comum ao acompanhamento da política. Inclusive, para Schudson (1998), o comportamento de monitoramento caracteriza uma nova onda de participação cívica da sociedade, que pode aproximar a população da política de forma ativa. Segundo o autor, o monitoramento democrático individual caracteriza um atual nível de cidadania na sociedade norte-americana. Contudo, um modelo ideal de cidadania democrática deveria contemplar indivíduos interessados e informados sobre o sistema político, não, necessariamente, apenas monitores deste sistema (SCHUDSON, 1998). Ou seja, importa a qualidade da participação e do conteúdo em debate e não a quantidade, visto que esta pode tornar a conversação ruidosa.

8 A compreensão sobre o ruído para a comunicação aparece, pela primeira vez, em Shannon e Weaver (1949) ao publicarem "A teoria matemática da comunicação", reduzindo o processo comunicacional à transmissão da mensagem de um emissor a um receptor por meio de um canal. Para os autores, o ruído é uma variável causal, que gera efeitos e altera a comunicação. Unidirecional, essa abordagem foi superada pelo desenvolvimento e consolidação de outras teorias que abordaram o processo de comunicação de maneiras mais complexas, considerando outras variáveis e comportamentos dos atores envolvidos. 
Empiricamente, em um estudo que avaliou o nível de monitoramento de cidadãos em países nórdicos, Hooghe e Dejaeghere (2007) elencaram quatro características intrínsecas a um monitor do tipo ideal. Para os autores, o cidadão que se torna monitor deve ter algum interesse político, esperar eficácia das instituiçóes políticas; estar em atividade de monitoramento e não depender de instituiçôes para entrar em contato de cobrança. Os pesquisadores transformaram tais atributos em categorias para analisar o quanto os indivíduos se aproximariam e se afastariam desse modelo ideal.

É importante destacar que, para Schudson (1998), o cidadão monitor não é passivo, mas tende a agir nos momentos em que acha serem ideais para isso. A ação de monitorar nesta perspectiva pode ser definida como estar próximo e atento às instituiçôes, para chamar a atenção delas quando achar necessário. O comportamento monitor do cidadáo é marcado, assim, pela atuação de vigilância no ambiente em que ele e as instituiçóes estão inseridos, não necessariamente coletando informaçôes para obter conhecimento sobre os fatos e as instituiçóes que acompanha (SCHUDSON, 1998).

Nota-se, assim, que a postura do cidadão monitor é pertinente ao comportamento dos indivíduos na esfera digital. Em ambientes on-line, esses monitores realizam uma varredura pelas informaçóes e não necessariamente se aprofundarem sobre elas, manifestando-se individualmente quando acharem necessário (VAN DEN HOVEN, 2005).

Hooghe e Dejaeghere (2007) indicam que essa individualização é uma característica do indivíduo pós-moderno, comportamento intrínseco à população mais jovem. E, logicamente, mais conectada. Para os autores, as novas geraçóes não estão, necessariamente, mais desinteressadas pela política, tampouco não buscam participar das conversaçóes que compóem o debate público; contudo, hoje, procuram formas e experiências não institucionalizadas e independentes para isso9. Nesse sentido, o monitor é um "vigilante" que se manifesta em relação a determinados temas de forma individual, sem a intermediação de instituiçôes.

9 Todavia, cabe ressaltar que, a partir de seus dados, os autores afirmam que os cidadãos pós-modernos - ainda que jovens, individualizados e com alta escolaridade - que se caracterizam como ativos e participativos politicamente na Escandinávia são os vinculados a partidos e sindicatos. Comportamento diferente, pois, da América e da Europa Ocidental (HOOGHE; DEJAEGHERE, 2007). 
Para Keane (2010), o comportamento passou a reconfigurar a democracia quando as pessoas desenvolveram o hábito de cobrar e julgar suas instituiçóes e representantes por meio do monitoramento. A análise empírica de Hooghe e Dejaeghere (2007) reforça isso ao mostrar que os questionamentos e as cobranças do cidadáo monitor direcionam-se ao sistema político e às suas instituiçôes, não à sociedade em si e aos concidadáos. É esse comportamento que pode acabar ampliando, portanto, o distanciamento entre a população e as instituiçóes políticas.

Pode-se afirmar que a principal diferença da caracterização do comportamento do cidadão monitor para a democracia está na percepção otimista de Schudson (1998) de que essa forma individualizada de participação não gera desgastes no relacionamento entre representantes e representados. Keane (2010), por sua vez, explora o enfraquecimento dessa relação. Para o autor, ainda que as instituiçóes representativas funcionem, elas têm que lidar com diversos outros agentes que se relacionam, incluindo um maior e intenso fluxo de comunicação e monitoramento entre as diferentes esferas. Assim, em Keane (2010), o excesso de monitoramento democrático não altera somente o comportamento da sociedade e desses novos monitores, mas das próprias instituições democráticas - por exemplo, os partidos, o parlamento e a imprensa - que, monitorados, passam a desempenhar suas funçôes sociais sob alerta constante.

O uso de novas tecnologias para a disponibilização de informaçôes do Estado poderia contribuir com a qualidade desse debate se os meios de comunicação e os monitores atuassem juntos, organizando o fluxo de informaçóes entre o campo político e a sociedade (SCHUDSON, 2010), o que não necessariamente acontece. Esses monitores são independentes e muitas vezes indivíduos que participam de forma isolada para cobrar açôes das instituiçóes sobre demandas muito particulares. Na esfera digital, isso também se amplia pelo fato de ela ser compreendida como um ambiente heterogêneo, fragmentado, saturado de demandas plurais, difusas e individuais (GROSSI, 2011; KEANE, 1995; SORJ, 2015).

Ressalta-se, pois, que os monitores sociais são muitos e plurais. $\mathrm{Ou}$ seja, os ruídos discutidos aqui não se dão de forma única. São múltiplos ruídos que surgem para que o Estado e a mídia tentem dar conta de responder a diversos grupos e demandas muito particulares. Além disso, a 
capacidade de produção de informações dos meios de comunicação, antes concentrada apenas em direção ao Estado e à sociedade, acaba multifacetada. $\mathrm{O}$ que também atinge a responsabilidade comunicativa do Estado, que até então somente dialogava com os meios de comunicação e com organizaçôes da sociedade civil. Nessa perspectiva, a ação dos monitores que produzem ruído, ao invés de fortalecer a comunicação entre os envolvidos, acaba enfraquecendo o debate público e, por sua vez, pode levar a um enfraquecimento da própria democracia. A seguir, aproximamos a discussão teórica do objeto empírico eleitoral digital para descrever aas particularidades da mídia jornalística, instituição mediadora e monitorada nas RSO.

\section{O jornalismo no debate eleitoral em redes sociais on-line}

$\mathrm{Na}$ democracia monitorada, o jornalismo perde a função exclusiva de orientar e mediar o debate e o comportamento públicos, uma vez que as informaçóes chegam aos cidadãos de outras formas e não precisam ser aprofundadas, investigadas. Dentro deste cenário, Zaller (2003) propóe um novo modelo de produção de notícias próximo a esse comportamento para indicar como o próprio jornalismo poderia agir muito mais na lógica de monitoramento: não necessariamente na produção de conhecimento, mas produzindo apenas alarmes à sociedade. Nesta nova proposta, o padrão de noticiário deveria ser mais superficial, acionando o cidadão a agir politicamente pela sociedade ao invés de fornecer informaçóes completas sobre as histórias pertinentes ao interesse público, como se dedicou a fazer ao longo do século XX. Contudo, ao assumir essa abordagem, o jornalismo deixa de defender seu próprio papel social, enquanto instituição organizadora do debate público, e passa a incentivar o comportamento independente dos cidadãos e a desorganizaçáo do Estado - a democracia monitorada.

Independentemente da forma como o jornalismo ainda atua ou padroniza seus produtos, prestando-se a informar ou apenas alarmar, cada vez mais as pessoas se informam simultaneamente sobre muitas coisas e de maneira superficial. Hoje, há um novo padrão de consumo de informações pela internet e de uso das RSO para a função de buscar informaçóes, inclusive políticas. Isso é consequência de uma série de fatores, que incluem as 
mudanças tecnológicas, a ubiquidade da comunicação on-line, a abundância comunicativa irrestrita, mas também do comportamento do próprio indivíduo com a notícia. Este, desinteressado de informaçóes e em debates qualificados sobre temas públicos, busca a instantaneidade e a superficialidade da informação, bem como aquele conteúdo que tende a reforçar sua opinião e sua visão de mundo.

Na compreensão de Schudson (2008), o jornalismo é uma instituição social importante para as democracias e deve colaborar com o monitoramento do sistema político. Contudo, como já considerado, cada vez mais é difícil creditar à imprensa a responsabilidade de direcionar o debate público, bem como a exclusividade de alimentá-lo. As conversaçóes digitais ilustram isso. Nessa era de abundância comunicativa, não há controle sobre a produção de conteúdos. Isso tudo é potencializado com as redes sociais, nas quais as organizaçóes se fazem cada vez mais presentes, como forma de relacionamento com o público e na tentativa de não perder seu espaço no mercado.

Considerando que os jornais possuem páginas no Facebook para informar seus seguidores sobre temas públicos, o espaço destinado aos comentários nessas publicaçóes torna-se mais um dos ambientes digitais destinados às conversaçóes públicas e políticas. Assim, aqui, o comentário monitor nas publicações jornalísticas no Facebook é aquele que descobre o espaço que poderia ser destinado exclusivamente ao debate sobre o tema da publicação - a campanha eleitoral no nosso caso - como uma oportunidade para cobrar e questionar as instituiçóes. Essas manifestaçóes individuais e em excesso aumentam de forma desorganizada os fluxos no processo de comunicação, saturando-o e gerando ruídos. Ressalta-se que a intensidade desses comentários pode dificultar não só o debate entre participantes sobre o tema pautado pelo post como também a própria relação entre a instituição e a população. Nesse cenário, os cidadáos acabam destinando o espaço que poderia aproximá-los de suas instituiçôes apenas para exercer a função de monitoramento e acabam, com isso, enfraquecendo as relaçôes de representação.

Deve-se considerar que as manifestaçóes estudadas aqui se dão dentro do debate digital - condicionado a diversas características específicas, tanto as próprias das RSO quanto as do comportamento do público -, o qual 
tem se assumido como mais polarizado e intransigente. Em ambientes virtuais, pode-se esperar que redes sociais como o Facebook tendem a suprimir o medo de expor a opiniáo individual perante o debate e às opinióes dominantes - o que pode ser esperado socialmente no debate público segundo a teoria espiral do silêncio (NOELLE-NEUMANN, 1995). Outros estudos que analisaram o uso do Facebook nas eleiçôes presidenciais brasileiras de 2014 indicaram que ele é um dispositivo que privilegia a radicalização entre internautas e a proliferação ideológica polarizada na rede (BRUGNAGO; CHAIA, 2014), além de ser palco para conversaçóes caracterizadas pela ausência de reciprocidade e justificativas externas para as manifestaçôes (MITOZO; MASSUCHIN; CARVALHO, 2017). Em relação à reciprocidade, os estudos de deliberação on-line têm se dedicado principalmente à sua dimensão direta, que "[...] revela-se na existência de uma troca mais explícita e imediata entre os participantes de um processo dialógico" (MENDONÇA; FREITAS; OLIVEIRA; 2014, p. 248). Inspirados em Jensen (2003), é a perspectiva adotada aqui, em que os comentários foram lidos e categorizados manualmente, identificando reciprocidade quando o comentador deixava explícita sua postura de abertura ao outro, ao diálogo, especialmente quando indicava que leu o conteúdo do post ou de outro comentário e se dirigia a seus autores. Considerando, ainda, que a reciprocidade é essencial para que se obtenha um cenário dialógico, com a articulação de diferentes discursos e pontos de vista (MENDONÇA; FREITAS; OLIVEIRA, 2014), a ausência dessa característica afasta o debate via conversação digital do debate público ideal. A não disposição ao discurso e opinião do outro conduz a discussão digital à monologia, tornando o ambiente digital em um espaço mais de manifestaçôes do que de debate.

É preciso afirmar também que as publicaçôes cujos espaços de comentários originam a conversação analisada aqui são jornalísticas. Por mais que o cenário descrito até seja marcado pela abundância comunicativa, cuja produção de conteúdo é descentralizada e horizontal, ressalta-se que o jornalismo também é compreendido enquanto instituição social (SCHUDSON, 2010). Quando os comentadores estão monitorando as notícias jornalísticas no Facebook, também estão fazendo isso como forma de acompanhar e cobrar a atuaçáo da imprensa na cobertura eleitoral. 
Assim, por mais que tratemos do Facebook como um ambiente não institucionalizado para a conversação pública e eleitoral, não se desconsidera o grau de institucionalização da mediação por meio dos jornais aqui. Como discutido na seçáo anterior, o comportamento monitor é em parte consequência de uma maior desconfiança nas instituiçôes democráticas (KEANE, 2010), o que, por sua vez, é resultado tanto da compreensão de que a instituição não está agindo como deveria quanto de que seus resultados são insatisfatórios (MOISÉS; MENEGUELLO, 2013). Isso também se aplica à imprensa, enquanto instituição social. Diversos trabalhos já indicaram que atuação jornalística em disputadas eleitorais tende a ser parcial e polarizada no Brasil (ALDÉ; MENDES; FIGUEIREDO, 2007; AZEVEDO, 2006, 2017). Tal comportamento da imprensa brasileira também pode influenciar maior volume de cobrança e críticas por parte dos cidadãos, inclusive nas RSO.

Ressalta-se que, aqui, nosso recorte de conversação pública é temático, eleitoral. Isso importa porque quando se pensa neste debate, também podemos considerar como ruídos aqueles comentários que discorrem sobre assuntos alheios ao tema eleitoral. Além do jornalismo, os partidos e os candidatos podem ser alvo de monitoramento por parte dos cidadãos que acompanham a cobertura eleitoral via Facebook. Para a análise empírica aqui, basta substituir o termo "Estado" no Quadro 1 por "campanha eleitoral". Assim, teríamos que os monitores entram em contato com organizações sociais, com a mídia e com as campanhas diretamente. Já a mídia, na análise empírica desse artigo, é representada pelos jornais brasileiros de referência: Folha de S. Paulo, O Estado de S. Paulo e O Globo, atuantes nas RSO' ${ }^{10}$.

O período eleitoral também é relevante por registrar maior participação do cidadão nas conversaçôes públicas, pois há um aumento do interesse sobre a política nos momentos decisórios. E isso também é válido para as discussóes on-line. Ainda que ambiente digital esteja inserido nesta lógica de abundância informativa, o cidadão tende a seguir determinadas ondas de interesse na internet, o que inclui o período próximo às eleiçôes (ALDÉ, 2011). A literatura já indica que há aumento de participação

10 Ressalta-se que, em 2014, quando os dados foram coletados e analisados, a Folha de S.Paulo publicava no Facebook. 
em conversaçôes via comentários on-line em publicações jornalísticas sobre eleiçôes (CERVI, 2013); inclusive em RSO como o Facebook (MITOZO; MASSUCHIN; CARVALHO, 2017). As pesquisas empíricas também mostram que isso se intensifica ao longo do tempo, No caso do nosso objeto empírico, já foi mostrado que "[...] os webleitores comentaram mais as eleiçôes presidenciais de 2014 no Facebook, conforme a decisão se aproximava, especialmente no segundo turno da campanha" (CERVI; CARVALHO; BUCKSTEGGE, 2015, p. 74). Passaremos, no tópico a seguir, a verificar isso por diferentes comportamentos desses comentadores.

\section{O debate eleitoral no facebook: uma proposta de tipologia}

Neste artigo, a aplicação empírica das consequências do modelo apresentado por Keane (2010) será feita no conjunto de comentários em publicaçôes sobre a campanha presidencial de 2014 no Brasil, nas páginas de três jornais diários brasileiros (Folha de S.Paulo, O Estado de S. Paulo e O Globo) no Facebook. Escolhemos os jornais de referência que migraram para as redes digitais por eles serem exemplos de mídia tradicional em espaços digitais de debate público. Como é o caso da rede social Facebook, onde há condiçóes ideais para a atuação e manifestação dos monitores sociais. Durante a campanha de 2014, a cobertura eleitoral e a conversação por meio de comentários foram constantes e intensos nas três fanpages jornalísticas (CERVI; CARVALHO; BUCKSTEGGE; 2015). Por meio da análise de conteúdo, classificamos manualmente todos os comentários, que citaram um dos três principais candidatos a presidente, feitos a postagens que também os citavam" ${ }^{\prime}$, delimitando assim o tema eleitoral da publicação na qual foi feito o comentário.

Uma das variáveis usadas para medir o tipo de participação é o "destinatário” do comentário. São sete destinatários possíveis (candidato, tema,

11 Os dados foram obtidos por meio do aplicativo Netvizz, disponivel na plataforma Facebook (RIEDER, 2013), selecionando a opção "page data" e os dados obtidos a partir dos posts publicados somente pela própria página. A coleta foi feita semanalmente durante o período eleitoral, de julho a outubro de 2014. A categorização, via análise de conteúdo, foi coletiva no âmbito do grupo CPOP (www.cpop.ufpr.br), da UFPR, com o aporte de um liuro de códigos para as variáveis categóricas. 
campanha, governo, portal, autor do post e internautas), além dos comentários que não têm destinatário explícito. Desses, os três primeiros indicam uma participação voltada para a finalidade direta do debate, que é eleitoral. Os outros quatro destinatários não estão diretamente relacionados à campanha, mas aos atores envolvidos no debate naquele ambiente. Já os comentários sem destinatário claro são considerados aqui "ruído" para o debate eleitoral.

A Tabela 1, a seguir, mostra a distribuição total dos comentários. São apresentados os números de comentários para cada destinatário $(\mathrm{N})$, o percentual total de comentários para os destinatários (\%TOT), o percentual por tipo de participação, se é sobre as eleiçóes ou sobre os próprios debatedores (\%TIPOS), e a última coluna mostra o total de comentários e o percentual em relação ao total em cada um dos dois tipos de participação, se é sobre o assunto ou sobre os demais debatedores.

Tabela I - Comentários por tipo de destinatário agregado por tipo de participação

\begin{tabular}{|c|c|c|c|c|c|}
\hline TIPO PARTICIP. & DESTINATÁRIO & $\mathbf{N}$ & $\%$ TOT & $\%$ TIPOS & SUBTOTAL \\
\hline \multirow{3}{*}{ Sobre eleições } & Ao candidato & 143.424 & 23,48 & 62,66 & \multirow{3}{*}{$231.397(37,89 \%)$} \\
\hline & Ao tema & 71.861 & 11,76 & 30,55 & \\
\hline & À campanha & 16.112 & 2,64 & 6,79 & \\
\hline \multirow{4}{*}{$\begin{array}{l}\text { Sobre } \\
\text { debatedores }\end{array}$} & Ao governo & 8.547 & 1,40 & 2,26 & \multirow{4}{*}{$57.131(9,36 \%)$} \\
\hline & Ao portal & 9.094 & 1,49 & 2,38 & \\
\hline & Ao autor & 11.092 & 1,82 & 2,95 & \\
\hline & Aos internautas & 28.398 & 4,65 & 7,50 & \\
\hline Ruído & Sem destinatário & 322.128 & 52,75 & 100 & $322.128(52,75 \%)$ \\
\hline \multicolumn{2}{|c|}{ TOTAL } & & & & $610.660(100 \%)$ \\
\hline
\end{tabular}

Fonte: Elaborada pelos autores (2017). 
Ao todo, foram coletados mais de 610 mil comentários $^{12}$ em publicaçóes que citavam um dos candidatos a presidente nas páginas em Facebook dos três jornais analisados aqui. Desse total, 38\% foram destinados ao assunto e quase $62 \%$ não tiveram como destinatário a campanha, um tema específico ou um candidato. Destaca-se, ainda, que maior parte dos comentários $(52,57 \%$ do total) não teve destinatário claro, caracterizando-os como "ruído" 13 para o debate eleitoral nessas páginas. O tipo de participação identificada como predominante aqui dificulta o debate por produzir conteúdos que contribuem pouco ou nada para o assunto em questão - no caso estudado, as eleiçóes nacionais.

Após identificar o volume de "ruído" no debate eleitoral, nossa análise exploratória se desenvolve em três etapas. Primeiramente, propóe-se uma tipologia a esses comentários, considerando características particulares no debate eleitoral. Depois, os diferentes comportamentos no debate são comparados condicionados por jornal e por candidato mencionado. Por fim, exploram-se séries temporais para cada um dos tipos de comentários aqui considerados por meio de autorregressóes.

\section{Tipologia para o comportamento na conversação sobre eleições no Facebook}

Para analisarmos o comportamento dos comentadores nas fanpages dos jornais de referência durante o período eleitoral de 2014, propomos uma tipologia que seja capaz de distinguir pelo menos três grandes tipos de comentários. O comentário "temático" é aquele que se refere ao tema do post, no caso, à campanha eleitoral. O comentário "monitor" é o que aparece no meio do debate eleitoral; porém, é dirigido não aos responsáveis pelas campanhas diretamente, mas às instituiçóes intermediárias do

12 Esses comentários foram feitos a um total de 14.794 posts de O Globo, O Estadão e Folha de S.Paulo em suas respectivas páginas no Facebook. Como foram selecionadas as publicações que textualmente citavam os três principais candidatos durante o periodo de campanha, considera-se aqui a disputa presidencial de 2014 como tema geral desses posts. Ressalta-se que tratamos de "debate eleitoral" ao analisar comentários que citavam candidatos em posts que os citavam. Não é nosso objetivo analisar o conteúdo desses posts neste artigo; contudo, outros trabalhos já publicados tiveram tais publicações como objeto de estudo. Ver mais informações em: Cervi, Carvalho e Buckstegge, 20 16; Cervi, Moreira e Carlomagno, 2015 e em Massuchin e Carvalho, 2016.

13 São exemplos os comentários: "Vote Dilma 13"; "Sou Aécio 45"; "\#Dilma 13"; "\#Marina”. 
debate. E o comentário "ruído" é o que não se dirige nem à campanha, nem às instituições intermediárias.

Como indicado anteriormente na Tabela 1, o critério para o estabelecimento da tipologia é o destinatário. A quem se destina o comentário foi usada para definir a qual categoria ele pertence. Se destinado ao candidato, ao tema ou à campanha, é comentário "temático". Se destinado ao governo, ao portal, ao autor ou aos internautas é comentário "monitor”, pois está no espaço de discussão sobre campanha eleitoral; porém, destinando-se aos atores intermediários do debate. Se não tem destinatário, é considerado "ruído", pois ele não está tentando conversar diretamente nem com os atores da campanha, nem com os intermediários, embora o conteúdo seja sobre a campanha eleitoral de 2014. Portanto, comporta-se como um elemento externo ao debate propriamente dito, aumentando o volume de fluxos e não contribuindo para a discussão acerca da temática eleitoral.

A Tabela 2, a seguir, sumariza os percentuais de participação dos tipos de comentários por fanpage dos jornais analisados aqui. A tabela anterior já havia indicado que do total de comentários, 52,75\% foi considerado "ruído". Ou seja, pouco mais da metade dos comentários feitos no âmbito da campanha eleitoral não se destinou a nenhum interlocutor, dificultando a sua participação em conversações. Em segundo lugar, está a categoria "temático", com 37,89\% do total de comentários e os restantes 9,35\% foi de comentário "monitor". O jornal Folha de S. Paulo (FSP) foi o que apresentou maior número de interaçóes no Facebook durante a campanha de 2014, representando 68,35\% do total de comentários analisados. Depois vem $\mathrm{O}$ Estado de S. Paulo (OESP), com 18,36\% dos comentários e O Globo (OGLO), com 13,27\%. 
Tabela 2 - Distribuição da tipologia de análise por fanpage de jornal

\begin{tabular}{l|c|c|c|c}
\hline \multirow{2}{*}{ JORNAL } & \multicolumn{4}{|c}{ TIPOLOGIA } \\
\cline { 2 - 5 } & Temático (\%) & Monitor (\%) & Ruído (\%) & Total (\%) \\
\hline FSP & $157.344(25,76)$ & $37.388(6,12)$ & $222.696(36,46)$ & $417.428(68,35)$ \\
\hline OESP & $52.223(8,55)$ & $12.721(2,09)$ & $47.193(7,72)$ & $112.137(18,37)$ \\
\hline OGLO & $21.834(3,57)$ & $7.022(1,14)$ & $52.239(8,55)$ & $81.095(13,27)$ \\
\hline TOTAL & $231.401(37,89)$ & $57.131(9,36)$ & $322.128(52,75)$ & $610.660(100)$ \\
\hline
\end{tabular}

Fonte: Elaborada pelos autores (2017).

Da distribuição percentual das tipologias, há uma concentração maior de percentuais de "ruído" na FSP, com 36,46\% do total, contra 7,72\% de OESP e 8,55\% de OGLO. Nessa categoria, o OESP é o jornal que menos contribui para o total. Nas outras duas categorias, as distribuiçóes percentuais seguem aproximadamente a mesma do total, com FSP representando quatro vezes mais que OESP e quase cinco vezes mais que OGLO.

O próximo passo da análise é a verificação da consistência interna da tipologia para identificação se os tipos como apresentados acima se distinguem internamente, ou seja, em função das demais características dos próprios comentários. Para tanto, serão utilizadas quatro variáveis para testar se as diferenças de médias da tipologia variam de maneira independente ou se elas apresentam alguma dependência de variaçóes. $\mathrm{O}$ esperado é que cada tipo de comentário apresente determinadas características que sejam distintivas dos demais tipos. Além dos testes chi-quadrado para verificar independência de médias da tipologia em relação às outras variáveis, nós usamos também os valores dos resíduos padronizados para caracterizar cada uma das categorias da tipologia proposta aqui.

Conforme descrito nas linhas inferiores do Gráfico 1, a primeira variável testada é o formato do comentário, que pode ser elogio ou crítica a qualquer um dos participantes das conversaçôes na fanpage (autor, portal, internautas, candidato ou governo). Outra variável testada é a que define se o comentário "é resposta" a outro ou não. Se for resposta, trata-se uma réplica a outro comentário. Se não é resposta, o comentário é elementar, feito diretamente à publicação. A terceira variável considerada é a postura 
adotada pelo comentador na conversa. Ela pode ser monológica, quando o comentário não expressa intenção de diálogo com os demais, ou de reciprocidade, quando há demonstração explícita de que o comentador leu e está respondendo a outro comentário no debate (DAHLBERG, 2004).

Outras duas características dos comentários foram extraídas das propostas de análise de Jensen (2003). Trata-se da reflexividade e da justificativa do comentário. A reflexividade pode ser de três tipos: i) persuasão, quando há sinais claros de que um comentador foi persuadido por outro ou que está disposto a persuadir; ii) progresso, quando indica que o comentador leu um comentário anterior e apresenta novos argumentos ou informações; iii) radicalização, quando há reação negativa a uma postagem que questiona posição anterior de um comentador. Os casos que não se enquadram em nenhuma das categorias foram desconsiderados. A justificativa do comentário também pode ser de três tipos: i) de posição, quando apenas afirma uma posição ou argumento, sem justificá-lo; ii) interna, quando usa de testemunhos próprios ou próprio ponto de vista para defender seus argumentos; iii) externa, quando usa fontes externas de informaçóes e dados públicos para defender sua própria posição (JENSEN, 2003).

O Gráfico 1, a seguir, mostra os resultados dos testes de chi-quadrado para cada uma das variáveis descritas acima com a tipologia de comentários. Todas as diferenças de médias são estatisticamente significativas, com coeficientes altos, o que indica que as distribuiçóes das categorias de cada uma das variáveis testadas não são independentes das variaçóes da tipologia. $\mathrm{O}$ coeficiente $\mathrm{V}$ de Cramer indica quanto de associação existe entre cada par de variáveis. Como se percebe, as associaçôes não são tão fortes quanto indicam os coeficientes de independência chi-quadrado. A mais forte associação de tipologia é com postura, com 41,3\% de associação das variaçóes. Em seguida vem formato, com $25,4 \%$ de associação, depois é resposta, com $23,9 \%$, reflexividade com $15 \%$ e a mais baixa associação foi com justificativa $(9,1 \%)$. 


\section{Gráfico I - Características internas da tipologia proposta}

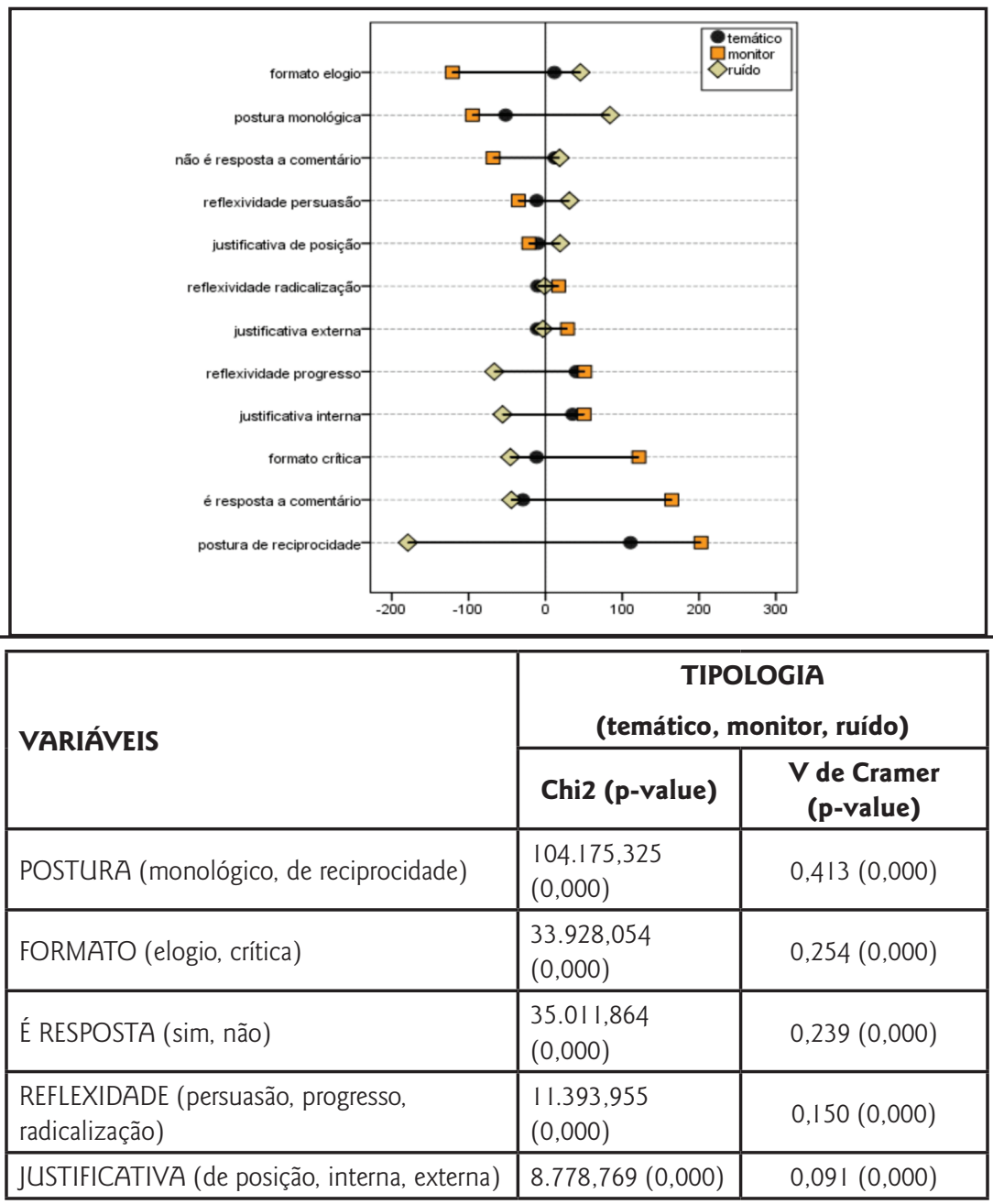

Fonte: Elaborado pelos autores (2017).

Quanto às características internas de cada tipo a partir das categorias das cinco variáveis, os resíduos positivos demonstram que para determinado tipo de comentário há mais presença da categoria. Assim, o Gráfico 1 indica que: 
- Tipologia temática, principalmente, apresenta formato de elogio, justificativa interna, reciprocidade e progresso como principal categoria de reflexividade. É um tipo de conversação típica; porém, usando próprias experiências quando se manifesta a respeito das eleições. Tende a não ser resposta direta a outro comentador.

- Tipologia monitor, formada principalmente por postura de reciprocidade, ser resposta a outro comentador, apresentar formato crítico, com justificativa interna e tendo progresso como reflexividade principal. Além dessas, também apresenta resíduos positivos para justificativa externa e radicalização. É um tipo com menos disponibilidade para conversação, mais crítico e com maior presença de informaçóes externas ao próprio comentador.

- Tipologia ruído, tende a ser monológico, no formato de elogio, não é resposta a outro comentador, a reflexividade é de persuasão e a justificativa de posição. É o típico comentário que usa de sua própria posição para justificar um elogio, além de não possuir destinatário e justificativa a partir da própria posição. O ruído é uma forma de expressão sobre o tema eleitoral, mas com conteúdo limitado à própria visão de mundo de quem faz o comentário.

O Gráfico 1, dessa forma, indica as associaçôes bivariadas de cada variável com a tipologia proposta. A seguir, no Gráfico 2, é apresentado o resultado do teste de múltiplas correspondências para verificar o quanto as categorias da tipologia são discriminadas em relação às categorias das demais variáveis, quando umas estão sendo controladas pelos efeitos das outras. Isso é necessário para identificar se os efeitos de uma variável não estão neutralizando os de outra. Por não apresentar variação, a variável se é ou não resposta não foi inserida no modelo. 


\section{Gráfico 2 - Teste de múltiplas correspondências}

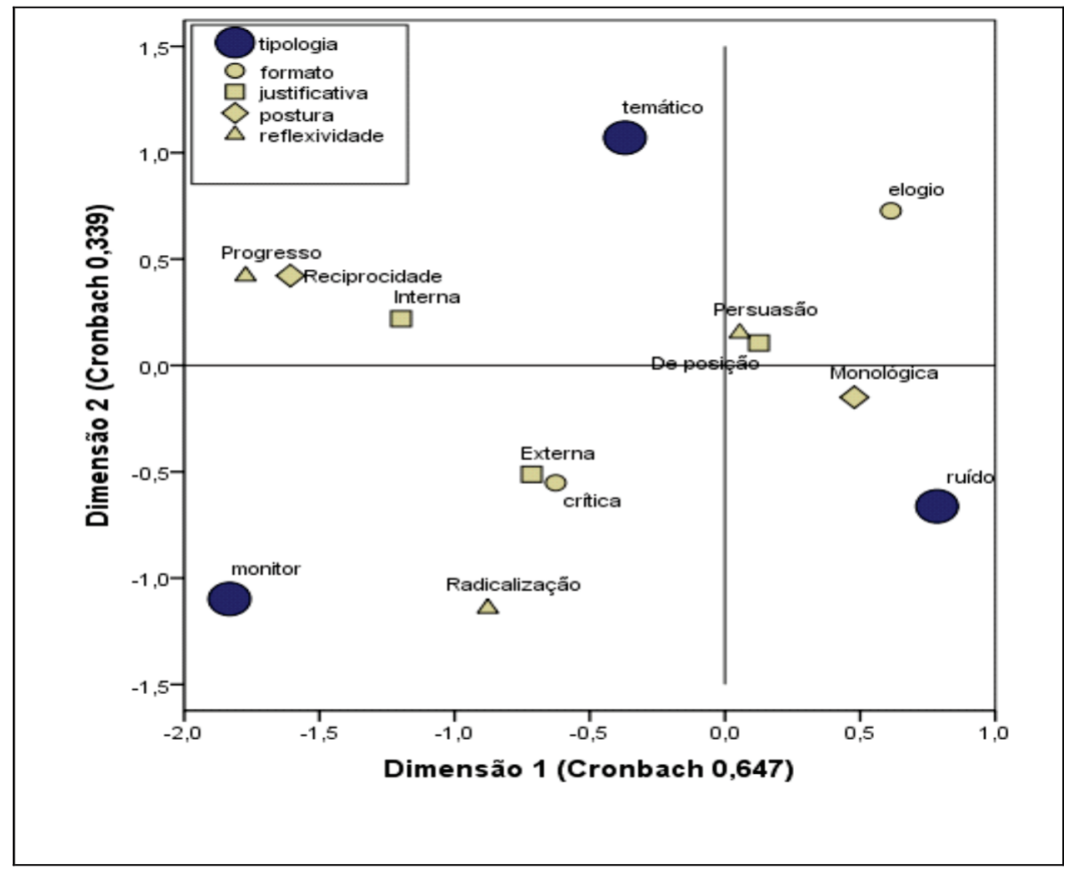

Fonte: Elaborado pelos autores (2017).

O resultado é um coeficiente alfa de Cronbach geral de 0,524 , que é considerado razoável por se tratar de análise exploratória e não para a produção de um índice. Ou seja, aproximadamente 52,4\% das variaçóes conjuntas de todas as variáveis explicam as diferenças entre as três categorias da tipologia proposta aqui. Com isso, é possível seguir adiante com a utilização da tipologia proposta.

O Gráfico 2 mostra que a capacidade explicativa da dimensão 1 (eixo horizontal) é de 0,647 , quase o dobro da explicação da dimensão 2 , que está em 0,339. Adotamos a análise das proximidades pela dimensão 1 . Percebe-se que cada categoria da tipologia fica em um quadrante. Ruído aproxima-se principalmente da postura monológica. Monitor está no mesmo quadrante de reflexividade por radicalização, formato crítica e justificativa externa. Já a categoria temática apresenta as maiores distância 
em relação às demais, embora esteja no mesmo quadrante de reflexividade tipo progresso, postura de reciprocidade e justificativa interna. Feitos os testes estatísticos de discriminação dos componentes internos da tipologia proposta, a partir daqui utilizamos os tipos de comentários para explorar os comportamentos por portal e pelo período da campanha.

\section{Tipos de comentários por jornal e candidato mencionado}

Feita a caracterização da tipologia e testada sua consistência interna, o próximo passo da análise é verificar como os tipos de comentários se distribuem entre os jornais quando os dois principais candidatos a presidente aparecem ou não nos comentários. Aqui, consideramos apenas os dois concorrentes que foram ao segundo turno: Dilma Rousseff - PT e Aécio Neves - PSDB e aplicamos a tipologia apenas aos comentários que citavam pelo menos um dos dois candidatos, em postagens dos três jornais analisados aqui, durante o período eleitoral. Isso para poder marcar que se trata do tema eleiçóes nacionais.

A Tabela 3, a seguir, mostra as distribuiçôes dos números de comentários e dos resíduos padronizados por jornal e considerando quando o candidato está ou não citado no comentário. A parte inferior da tabela mostra os totais de casos por jornal. Nela, estão destacados os valores dos resíduos padronizados por tipologia e por jornal. Esses valores depois são comparados com os encontrados quando o comentário cita um dos dois candidatos. Os testes de diferenças de médias indicam coeficientes de chi-quadrado muito acima do limite crítico de rejeição da hipótese nula, o que nos permite afirmar que as tipologias náo variam de modo independente do jornal e da presença do candidato. No entanto, ressalta-se que o coeficiente de associação V de Cramer gira em torno de $10 \%$ para todas as categorias.

Os valores dos totais na parte inferior da Tabela 3 a seguir mostram que o tipo "ruído" aparece predominantemente em OGLO, com resíduos padronizados de 45,7, enquanto OESP concentra maior participação de comentários do tipo "temático" (47,2 de resíduo) e "monitor" (21,8 de resíduo). O jornal FSP apresenta distribuição mais próxima da média apresentando resíduos muito baixos (cerca de zero) para as três categorias. 


\section{Tabela 3 - Comparações das tipologias por jornal e presença de candidato em 2014}

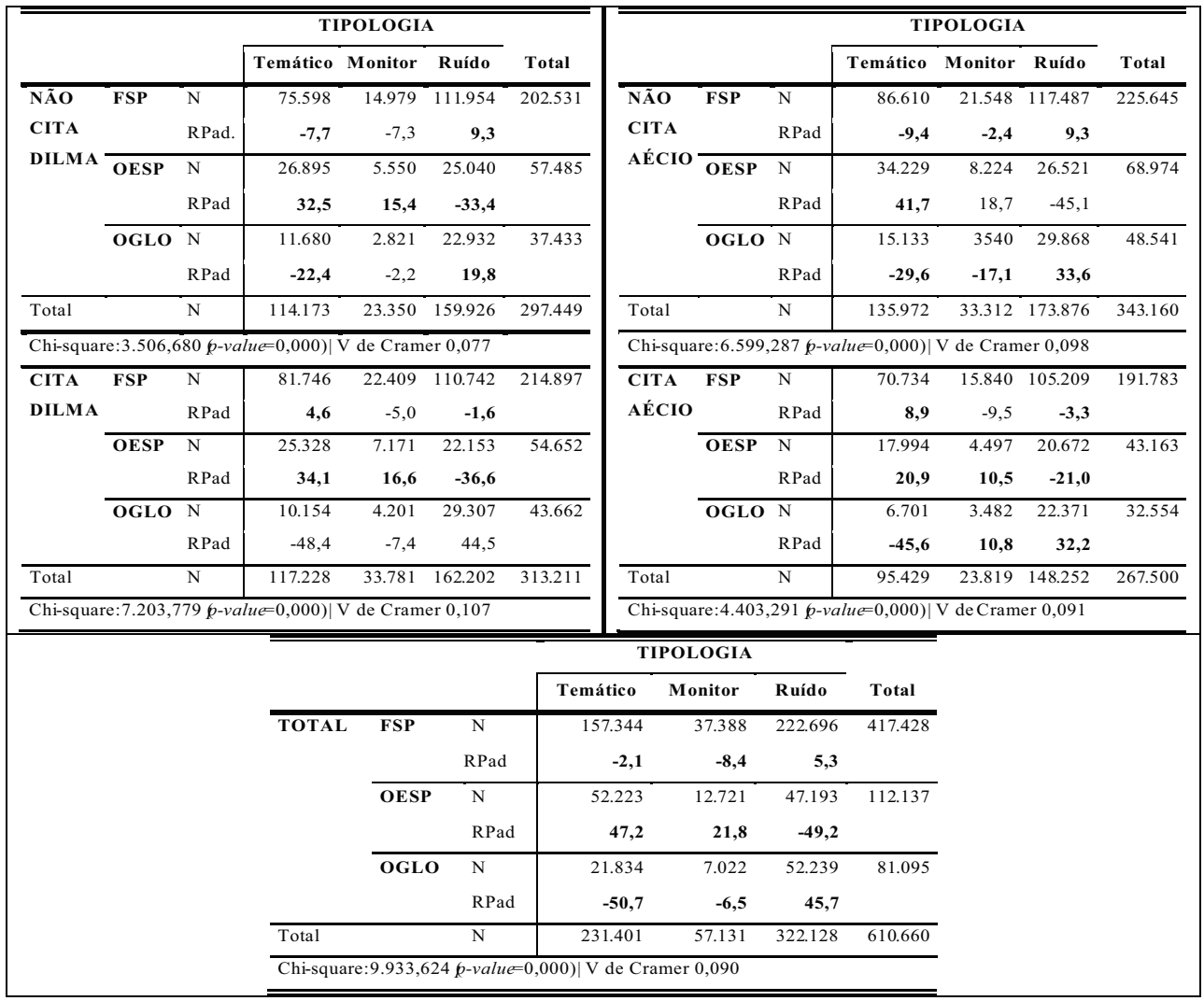

Fonte: Elaborada pelos autores (20/7).

Tendo comparado os tipos por jornais, passamos a verificar se isso se altera com a presença e com a ausência da citação de cada um dos candidatos no comentário. A análise se dá por meio da comparação dos resíduos para os candidatos, expostos na parte superior, com os resíduos dos tipos para cada jornal, aqueles da parte inferior da Tabela 3. Se o resíduo fica abaixo do total, ele é marcado em vermelho; se acima, está em azul. Com isso, podemos identificar quando a presença do candidato no comentário aumenta ou diminui a possibilidade de encontrar determinada tipologia de comentário na fanpage de um dos jornais analisados aqui. 
Quando comparamos os resíduos apresentados em comentários que citam os candidatos por jornal, na FSP há mais presença de comentários "temáticos" e menos de "ruído" quando são citados Dilma e Aécio. Em OESP, quando o comentário cita Aécio há menos presença dos três comentários em relação ao total. No caso de Dilma, cresce a presença de "ruído" na fanpage do jornal quando a candidata à reeleição é citada no comentário. Já em OGLO não há diferenças significativas para os três tipos quando Dilma é citada no comentário, enquanto que para Aécio diminuem as presenças de "temático" e "ruído" ao mesmo tempo em que aumenta a participação de "monitor".

Se não citam Dilma, os comentários na fanpage da FSP tendem a ser mais "ruído" e na ausência de Aécio tendem a ser mais "monitor" e "ruído". Em OESP, os comentários tendem a ser mais "ruído" quando não citam Dilma e mais "temático" quando não citam Aécio. Em OGLO, eles são mais "temáticos" e menos "ruído" sem Dilma e mais "temático" e menos as outras duas categorias se Aécio não é citado.

\section{Comportamentos dos comentários ao longo do tempo}

Os resultados analisados na Tabela 3 mostram variaçóes gerais em relação às categorias por jornal e candidato. No entanto, a literatura sobre conversaçóes on-line e campanhas eleitorais indica a variação do tempo como fator importante para explicar mudanças no padrão das manifestaçóes (CERVI; CARVALHO; BUCKSTEGGE, 2015). Quanto mais tempo há de campanha, maior o acúmulo de novas informaçôes e/ou maior disposição para manter posiçôes já apresentadas nos diálogos anteriores. Por conta disso, a última etapa da análise exploratória realizada aqui utiliza técnicas de autorregressão temporal para identificar padróes de comportamento ao longo do tempo para os tipos de comentários no geral e por fanpage de jornal. Não utilizaremos nenhum regressor externo. Nosso objetivo é identificar se apenas a passagem do tempo (o decorrer da campanha) é suficiente para indicar alguma mudança no volume de comentários por tipo.

Aqui são apresentados dois coeficientes principais: o r2 estacionário, que indica quanto há de estacionaridade em uma variável, ou seja, de não mudança dos valores ao longo do tempo; e o coeficiente Ljung-box 
acompanhado do $p$-value, que indica quanto de mudança da variável pode ser explicada pela passagem do tempo. Aqui, o coeficiente Ljung-box será usado para comparar os tamanhos das diferenças ao longo do tempo entre os jornais e em relação ao total, pois, por ser um coeficiente adimensional, ele pode ser usado para comparaçóes diretas. A unidade temporal utilizada aqui é o dia da publicação do comentário. De $1^{\circ}$ de julho a 31 de outubro de 2014, são 123 dias de postagens de comentários. Foram agregados os comentários registrados por dia e as variaçóes desses totais diários é que estão sendo testadas aqui.

No primeiro quadrante do Quadro 2, a seguir, estão os coeficientes para o conjunto de todos os comentários nos três jornais durante todos os 123 dias de campanha eleitoral analisados aqui. Os coeficientes mostram que há variaçóes estatisticamente significativas ao longo do tempo para a categoria "temático" e a categoria "ruído". Elas crescem no final do período em relação ao início. O r2 estacionário deles é baixo e os coeficientes Ljung-box são mais altos. Já a categoria "monitor" não apresenta grandes variaçóes ao longo do tempo, mantendo a presença diária nos comentários próxima de uma média em todo o período. Isso é indicado no maior coeficiente $\mathrm{r} 2$ estacionário $(0,380)$. A importância de também apresentar os resultados por fanpage de jornal no Quadro 1 reside no fato de que eles mostram que as variaçóes temporais significativas acontecem apenas em OGLO. Nos outros dois jornais, os coeficientes são baixos, indicando que a presença dos tipos de comentários não sofreu grandes alteraçóes ao longo da campanha. 
Quadro 2 - Resultados das séries temporais para total e por fanpage de jornal

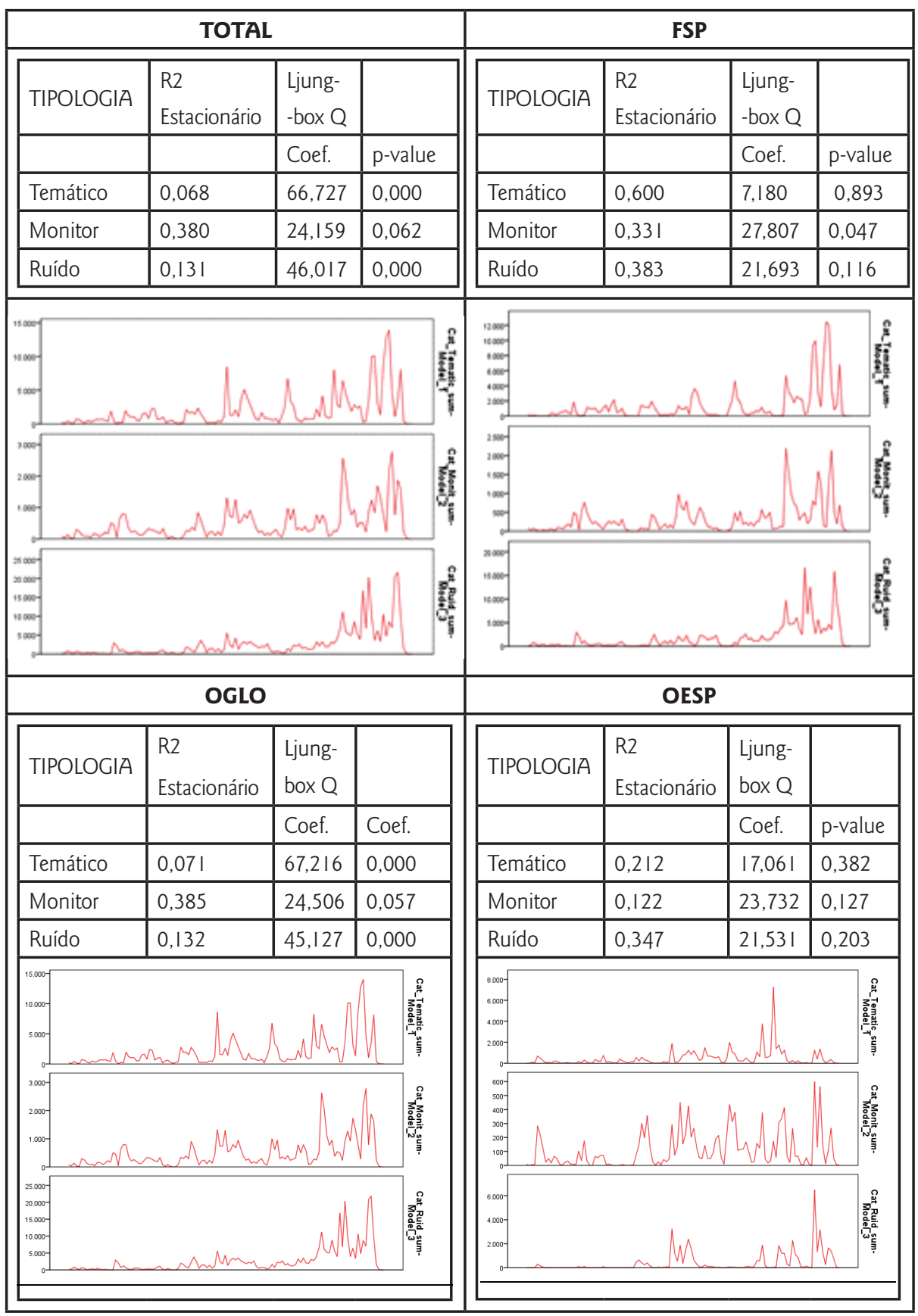

Fonte: Elaborado pelos autores (2017). 
Em OGLO, o maior crescimento temporal se dá em comentários temáticos (coef. $=67,216$ ), seguido de ruído (coef.=45,127). No caso dos comentários temáticos, o coeficiente em OGLO é maior que o total, inclusive. Já o tipo monitor fica com menor coeficiente e com p-value muito próximo do limite crítico. Em relação aos outros dois jornais, o OESP é o que apresenta as menores variaçóes temporais. Na FSP, apenas o comentáriomonitor apresenta um coeficiente que indica crescimento ao longo do tempo. As outras duas categorias são mais estacionárias. Esses resultados mostram que, para os 123 dias de campanha, os comentadores das fanpages de FSP e OESP tenderam a manter o mesmo padrão geral de comportamento em seus comentários. Já em OGLO, há crescimento de temático e de ruído nos comentários ao final da campanha, quando comparado ao período inicial.

Uma informação adicional fornecida pelos gráficos que constam no Quadro 2 é a maior variação diária nos números de comentários por categoria ao final do período em relação ao início. Essas variaçóes parecem coincidir com a mudança de turno eleitoral. Por este motivo, acrescentamos uma comparação dos coeficientes Ljung-box por turno eleitoral, fanpage e tipo de comentário. O objetivo com este teste adicional é verificar se há crescimento significativo da presença de comentários por tipo e por jornal entre o primeiro e segundo turnos da eleição de 2014.

Como indica o Quadro 3, a seguir, há grandes diferença para quase todas as categorias e fanpage, o que mostra que considerar as manifestaçóes em redes sociais durante campanhas eleitorais sem distinguir os turnos pode resultar em conclusôes errôneas. Os dados discutidos aqui demonstram que, em relação às manifestaçóes nas fanpages desses três jornais, há dois comportamentos distintos dos comentadores, um para o primeiro turno e outro para o segundo, com intensificação do último em relação ao primeiro, quase como se fossem duas campanhas distintas. No entanto, nem todas as diferenças foram no mesmo sentido, como esperado inicialmente. Houve também redução na presença de algumas categorias de comentários no segundo turno em relaçáo ao primeiro.

O gráfico do Quadro 3 mostra que apenas a categoria "ruído" apresenta crescimento de coeficiente Ljung-box do segundo turno em relação 
ao primeiro. Isso indica que, durante os quase 30 dias do segundo turno, a presença desse tipo de comentário aumentou mais do que o que foi registrado nos mais de 90 dias do primeiro turno. $\mathrm{O}$ mesmo aconteceu com os comentários temáticos para OGLO e FSP, enquanto que, em OESP, o volume de crescimento diário de comentários temáticos no segundo turno foi menor que no primeiro. Por outro lado, o tipo monitor foi o que apresentou as maiores variaçóes entre jornais. Ele cresceu no segundo turno em relação ao primeiro em OGLO, ficou estável, com diferença de coeficiente muito próximo de zero, para FSP e apresentou queda em OESP.

Quadro 3 - Comparação dos coeficientes da série temporal por jornal e tipologia entre $1^{\circ}$ e $2^{\circ}$ turnos

\begin{tabular}{|c|c|c|c|c|c|c|c|c|}
\hline & \multicolumn{4}{|c|}{ Ljung-box $\mathbf{Q}$} & \multirow{2}{*}{ مَ } & 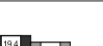 & & \multirow{2}{*}{ 159 } \\
\hline & $1^{\circ} \mathrm{T}$. & $2^{\circ} \mathrm{T}$ & Dif. & & & 낭의 & & \\
\hline \multirow[t]{3}{*}{ OGLO } & Temático & ।,966 & 21,374 & 19,408 & هั & & & \\
\hline & Monitor & 2,930 & 10,672 & 7,742 & 茕 & & & (1) \\
\hline & Ruído & 5,808 & 15,239 & 9,431 & 弯 & & & \\
\hline \multirow[t]{3}{*}{ FSP } & Temático & 27,334 & 46,325 & 18,991 & : & & & \\
\hline & Monitor & 12,202 & 11,779 & $-0,423$ & & & 因 & \\
\hline & Ruído & 11,636 & 27,576 & 15,940 & 这 & & & \\
\hline \multirow[t]{3}{*}{ OESP } & Temático & 10,368 & 5,262 & $-5,106$ & 总 & & & \\
\hline & Monitor & 24,295 & 17,550 & $-6,745$ & 产 & & & $\begin{array}{l}\text { Ooglobo } \\
\text { Golnassopaulo }\end{array}$ \\
\hline & Ruído & 16,545 & 26,073 & 9,528 & & Tenálico & Montor & Ruido \\
\hline
\end{tabular}

Fonte: Elaborado pelos autores (2017).

Os coeficientes apresentados no Quadro 3, por jornal e categoria de comentário, mostram comportamentos distintos dos comentadores das três fanpages. No caso de OGLO, as diferenças são positivas (indicadas em azul) para as três categorias, com maior destaque para o crescimento de comentários temáticos (diferença de 19,408). Em a FSP, há crescimento também elevado para temático (diferença de 18,991) e ruído $(15,940$ de diferença). Já os comentários de tipo monitor têm diferença muito próxima a zero entre os dois turnos. No caso de OESP, há queda no crescimento de temático e monitor no segundo turno em relação ao primeiro e crescimento da presença de ruído. 


\section{Considerações finais}

Em sociedades democráticas monitoradas e inseridas numa lógica de abundância comunicativa, nota-se cada vez mais a desorganização das relaçôes entre instituiçôes e cidadãos, entre representantes e representados. Considerando que o debate público passa por transformaçóes significativas e deixa de ser estruturado verticalmente, sem mediaçóes institucionais, partimos de um caso para discutirmos como a configuração dada pelos novos fluxos de comunicação, com ações isoladas de indivíduos, especialmente por meio da internet, permite o aumento de ruídos no processo comunicativo do debate. Aqui, aplicamos a análise ao caso específico de uma disputa eleitoral. É possível que em outros contextos os resultados sejam distintos. Tais consideraçóes são ampliadas, ainda, dentro das redes sociais on-line (RSO), como demonstramos aqui a partir da análise da conversação dos brasileiros sobre campanha.

Com este trabalho, propomos e testamos uma tipologia do comportamento do comentador no Facebook, que busca interagir e debater sobre temas políticos nas RSO, especialmente em espaços informativos, alimentados por instituições intermediárias do debate público tradicional. Assim, é importante também ponderar que, por mais que se classifique e defenda o ambiente digital das RSO como não institucional para o debate público, há a medição intermediária de instituições convencionais nesse papel, como a imprensa, que publica nesses espaços. Neste caso, o recorte se dá para o caso específico da conversação sobre as eleiçóes presidenciais de 2014 a partir da cobertura da imprensa de referência nacional no Facebook. Nossa tipologia contempla três categorias de comportamento a partir do destinatário da mensagem e mostrou-se consistente para identificar se o mesmo é temático, monitor ou ruído. Ou seja, obtivemos diferenças significativas entre as características de cada tipo, o que possibilitou avanço do nosso trabalho em três etapas analíticas.

Em nossa análise empírica, primeiramente, mensuramos a quantidade de comentários controlados pela tipologia. Destacamos que "ruído" concentrou mais da metade dos comentários, como expóe a Tabela 1. Isso é consequência das características da plataforma Facebook e do constante uso das redes sociais pelos indivíduos para se expressarem de modo 
particularizado, uma vez que essa tipologia concentra comentários mais limitados às justificativas de posição e independentes do tema em debate. Além disso, um terço do debate foi "temático" e o comportamento do tipo "monitor" esteve presente em apenas cerca de 10\% do total de comentários. Em relação aos jornais, encontramos diferenças quantitativas pertinentes à concentração do debate. Como indica a Tabela 2, destaca-se a fanpage da Folha de S. Paulo (FSP), que obteve muito mais comentários que as outras duas páginas e concentrou $68,35 \%$ do total de comentários, contra $18,36 \%$ no jornal O Estado de S. Paulo (OESP) e 13,27\% em O Globo (OGLO).

A segunda etapa da análise também permitiu identificar diferenças de comportamento dos comentadores por jornal. A Tabela 3 expôs essas informaçóes e indicou que os comentários são mais temáticos na FSP quando os candidatos são citados. No caso de OESP, a informação obtida pela análise comparativa é de que há mais ruído quando Dilma, candidata à reeleição, era mencionada no comentário. Por sua vez, o comportamento do comentador de OGLO tende a ser mais de monitor quando se menciona o nome de Aécio Neves.

Outra diferença percebida em relação aos comportamentos dos comentadores por fanpage diz respeito ao volume de comentários ao longo da campanha, conforme foi explorado no Quadro 2. Apenas em OGLO há variaçôes significativas durante a campanha, indicando que os comentadores do jornal tenderam a mudar o comportamento ao longo do tempo. No caso de OESP, houve estacionaridade em praticamente todo o período. $\mathrm{Ou}$ seja, os volumes de monitores, temáticos e ruídos tenderam a se manter estáveis ao longo do tempo. Em a FSP, a diferença se dá apenas no volume diário de comentário monitor, ou seja, nessa fanpage os comentadores tenderam a discutir mais com os atores intermediários ao debate no final da campanha em relação ao início.

Por fim, encontramos mudanças nos padróes de comportamento nas três fanpages do segundo turno em relação ao primeiro. É possível pensar que o crescimento nas manifestaçóes via comentários em fanpage dos jornais coincide com a polarização da campanha e com o maior volume de informaçóes sobre ela, como indicam os dados expostos no Quadro 3. Isso 
porque a disputa passa a ser concentrada apenas em dois candidatos e já há um acúmulo de informaçóes sobre as eleiçôes após os 90 dias do primeiro turno. No entanto, esse crescimento não se dá de modo homogêneo, nem em relação à tipologia, nem aos jornais.

Nossos dados mostraram que o único tipo de comentário que cresceu nos três jornais no segundo turno em relação ao primeiro é "ruído". Esse achado nos permite afirmar que o maior volume de manifestaçôes no segundo turno não significa, necessariamente, maior qualidade dos conteúdos publicados pelos eleitores via comentários em redes sociais ao final da campanha. Por outro lado, há crescimento da categoria "temático" em dois dos três portais, ainda que em OESP ele tenha apresentado queda no segundo turno. Por outro lado, vale ressaltar que as diferenças de coeficientes entre "temático" e "ruído" ficaram muito próximas no geral, nas três fanpages. A categoria monitor foi a que apresentou maiores diferenças entre os três jornais. A presença dela cresce no segundo turno em OGLO, fica estável na FSP e cai em OESP.

A análise empírica desenvolvida a partir dos conceitos de monitoramento de Keane (2010) também permite ponderar as afirmaçóes normativas do autor, segundo as quais, em determinados ambientes de abundância comunicacional haveria proliferação de comportamento de monitor social. Não foi o que encontramos na análise das conversaçôes em Facebook durante a campanha presidencial de 2010. Em média, o comportamento monitor dos jornais por parte dos comentadores girou em torno de $10 \%$ do total de participaçóes, muito aquém do que se esperava inicialmente. A título de comparação, o ruído propriamente dito, aquele que não trata do tema e não monitora as instituições, foi cerca de cinco vezes superior ao comportamento monitor na média dos três jornais. Assim consideramos ser necessário aplicar o conceito em outros estudos empíricos para continuar testando a intensidade de monitores sociais em diferentes contextos.

Assim, para além de contribuir com a tipologia e indicar o volume significativo de ruído existente nas conversaçóes em RSO, nossos dados indicam que o debate digital eleitoral se deu de modo distinto nas três fanpages. Isso nos permite reafirmar que para o tipo de manifestação de monitores - aqueles que vigiam, criticam e cobram os intermediadores do debate 
- importa a instituição que está sendo monitorada. Neste caso, o veículo de imprensa que publica sobre a campanha eleitoral em sua fanpage.

\section{Referências}

ALDÉ, A. O internauta casual: notas sobre a circulação da opinião pública na internet. Revista USP, São Paulo, v. 90, n. 2, p. 24-41, 2011.

ALDÉ, A.; MENDES, G. G.; FIGUEIREDO, M. Tomando Partido: Imprensa e política nas eleiçóes de 2006. Política \& Sociedade, v. 10, p. 153-172, abr. 2007.

AZEVEDO, F. A. Democracia e mídia no Brasil: um balanço dos anos recentes. In: GOULART, J. A. (Org.). Mídia e democracia. São Paulo: Annablume, 2006. p. 23-46.

AZEVEDO, F. A. A Grande Imprensa e o PT: 1989-2014. São Carlos: Edufscar, 2017.

BRUGNAGO, F.; CHAIA, V. A nova polarização política nas eleiçôes de 2014: radicalização ideológica da direita no mundo contemporâneo do Facebook. Revista Aurora, São Paulo, v. 7, n. 21, p. 99-129, 2014.

CERVI, E. U. Opinião Pública e Comportamento Político. Curitiba: IBPEX, 2010.

CERVI, E. U. Como os webleitores do "Portal Estadão" comentaram a eleição de Dilma Rousseff em 2010: uma discussão sobre os participantes do debate público em campanhas eleitorais nos novos meios de comunicação. Explanans, Zinacantepec, México, v. 2, n. 1, p. 75-99, 2013.

CERVI, E. U.; CARVAlHO, F. C.; BUCKSTEGGE, J. A Disputa Presidencial em posts e comentários no Facebook. Em Debate, v.7, n. 5, p. 47-75, 2015.

CERVI, E. U.; MOREIRA, A. C. M.; CARLOMAGNO, M. C. Existe polarização nas postagens de Facebook de periódicos brasileiros durante as eleiçốes? Revista Observatório, v. 1, n. 3, p. 119-140, 2015.

COLEMAN, S. New mediation and direct representation: reconceptualizing representation in the digital age. New Media \& Society, v. 7, n. 2, p. 177-198, 2005.

DAHLBERG, L. Net-public sphere research: beyond the "first phase". The Public, v. 11, p. 27-44, 2004.

FEENSTRA, R. A. Democracia en la era de la nueva galaxia mediática. Veritas, v. 57, n. 1, p. $112-$ $127,2012$.

FUKS, M. Definição de agenda, debate público e problemas sociais. BIB, n. 49, p. 79-94, 2000.

GROSSI, G. La Opinion Publica. Madrid: Centro de Investigaciones Sociológicas, 2007.

GROSSI, G. Sfera pubblica e flussi di comunicazione nell'epoca della rete. In: MOSCA, L.; VACCARI, C. (Org.), Nuovi media, nuova politica? Partecipazione e mobilitazione online. Milano: Franco Angeli, 2011.s/p. 
HELD, D. Modelos de democracia. Madrid: Alianza Editorial, 1996.

HOOGHE, M.; DEJAEGHERE, Y. Does the "monitorial citizen" exist? An empirical investigation into the occurrence of postmodern forms of citizenship in the Nordic countries. Scandinavian Political Studies, v. 30, n. 2, p. 249-271, 2007.

JENSEN, J. L. Public spheres on the internet: anarchic or government-sponsored - a comparison. Scandinavian Political Studies, v. 26, n. 4, p. 349-374, 2003.

KEANE, J. Structural transformations of the public sphere. The Communication Review, v. 1, n. 1, p. 1-22, 1995.

KEANE, J. Vida e Morte da Democracia. São Paulo: Edições 70, 2010.

MASSUCHIN, M.; CARVALHO, F. C. Conteúdo jornalístico nas redes sociais: as estratégias dos jornais brasileiros no Facebook. Textual \& Visual Media: revista de la Sociedad Espańola de Periodística, n. 9, p. 155-176, 2016.

MENDONÇA, R. F.; FREITAS, F. V.; OLIVEIRA, W. M. Reciprocidade discursiva, enquadramento e deliberação: a consulta pública sobre reforma política da ALMG. Análise Social, n. 211, p. 244$271,2014$.

MITOZO, I.; MASSUCHIN, M.; CARVALHO, F. C. Debate político-eleitoral no Facebook: os comentários do público em posts jornalísticos na eleição presidencial de 2014. Opiniáo Pública, v. 23, n. 2, p. 459-484, maio 2017.

MOISÉS, J. A., MENEGUEllO, R. Os efeitos da Desconfiança Política para a Legitimidade Democrática. In: MOISÉS, J. A.; MENEGUELLO, R. (Org.). A Desconfiança Política e os seus Impactos na Qualidade da Democracia. São Paulo: Edusp, 2013. p. 11-24.

NOELLE-NEUMANN, E. La Espiral del Silencio: Opinión Pública nuestra piel social. Barcelona: Paidós, 1995.

RIEDER, B. Studying Facebook via data extraction: the Netvizz application. In: ACM. Proceedings of the 5th annual ACM web science conference. Paris: ACM, 2013. p. 346-355.

RUBIM, A. A. C. Novas Configuraçôes das Eleiçôes na Idade Mídia. Opiniáo Pública, v. 7, n. 2, p.168-181, 2001.

SCHÄFER, M. Digital Public Sphere. In: MAZZOLENI, G. (Ed.). The International Encyclopedia of Political Communication. Milano: John Wiley \& Sons, 2015. s/p.

SCHUDSON, M. The good citizen: A history of American civic life. Free Press, 1998.

SCHUDSON, M. Why Democracies Need an Unlovable Press. Malden: Polity Press, 2008.

SCHUDSON, M. Political observatories, databases \& news in the emerging ecology of public information. Daedalus, n. 139, p.100-109, 2010.

SHANNON, C. E.; WEAVER, W. The mathematical theory of communication. Urbana: University of Illinois Press, 1949. 
SORJ, B. On-line/off-line: a nova onda da sociedade civil e a transformação da esfera pública. In: SORJ, B.; FAUSTO, S. (Org.). Internet e mobilizaçóes sociais. São Paulo: Ediçôes Plataforma Democrática, 2015.

VAN DEN HOVEN, J. E-democracy, E-Contestation and the Monitorial Citizen. Ethics and Information Technology, v. 7, n. 2, p. 51-59, 2005.

ZALLER, J. A new standard of news quality: Burglar alarms for the monitorial citizen. Political Communication, v. 20, n. 2, p. 109-130, 2003.

\section{Electoral conversation in monitored democracies: a typology for analysis of comments in online social networks}

\section{Abstract}

The article discusses how the communicative abundance enhanced by online spaces affects the organization of contemporary conversations in monitory democracies. It is discussed how social monitors generate specific communication flows to institutions and political actors in online social networks. The behavior of the online conversation about the Brazilian elections in 2014 is analyzed from 610 thousand comments at Folha de S. Paulo, O Estado de S. Paulo and O Globo fan pages on Facebook. The research question is: do the commentators in the three newspapers' fan pages have similar behaviors? Also, it is proposed a typology to classify the comments. Among the results obtained, the volume of noise in the digital electoral debate is higher than the thematic comments.

Keywords: Monitory Democracy. Digital conversation. Elections 2014. Noise. Monitors.

Recebido em: 25/03/2018

Aprovado em: 21/08/2018 